\section{Evaluation of antibacterial activity and acute toxicity of pomegranate (punica granatum I.) seed ethanolic extracts in swiss webster mice}

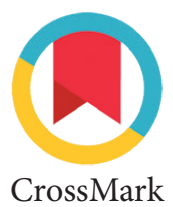

\author{
Riani Setiadhi, ${ }^{1 *}$ Irna Sufiawati, ${ }^{1}$ Dewi Zakiawati, ${ }^{1}$ Nanan Nur'aeny, ${ }^{1}$ Wahyu Hidayat, ${ }^{1}$ \\ Dani R. Firman ${ }^{2}$
}

\title{
Abstract
}

Objective: To evaluate the safety of a pomegranate seeds ethanolic extract in Swiss webster mice.

Material and Methods: Pomegranate seed's ethanolic extracts were evaluated for minimum inhibitory concentration against streptococcus sanguis ATCC 10556, using microdilution method through 96-wells microplate. In acute toxicity test, 12 females and 12 males Swiss Webster mice weighing 20-30 grams were divided into four groups, each consisting of 3 females and 3 males. Three groups were orally given of sample with concentrations $0.2 \%$ equivalent to $40 \mathrm{mg} / \mathrm{kg}$, $0.4 \%$ equivalent to $80 \mathrm{mg} / \mathrm{kg}$, and $0.8 \%$ equivalent to $160 \mathrm{mg} / \mathrm{kg}$, while the control group was given distilled water. Observations were made at 30,60 and 90 minutes, for 24 hours and 7 days.

Results: The MIC against streptococcus sanguis was on 2000 ppm concentration and until 24 hours observation no lethal effect occurred on the mice, but at the 7 days observation in the group of $0.8 \%$ per kilogram body weight, the lethal effect occurred at one mice.

Conclusion: The ethanolic extract of pomegranate seeds has antibacterial effect and no acute systemic toxicity, which can be considered safe on the use as oral topical solution since the toxic dose is greater than $160 \mathrm{mg} / \mathrm{kg}$ of body weight.

Keywords: Pomegranate, Ethanolic extract, Acute systemic toxicity

Cite this Article: Setiadhi, R., Sufiawati, I., Zakiawati, D., Nur'aeny, N., Hidayat, W., Firman, D.R. 2017. Evaluation of antibacterial activity and acute toxicity of pomegranate (punica granatum I.) seed ethanolic extracts in swiss webster mice. Journal of Dentomaxillofacial Science 2(2): 119-123. DOI: $10.15562 / j \mathrm{dmfs} . \mathrm{v} 2 \mathrm{i} 2.536$

'Department of Oral Medicine, Faculty of Dentistry, Padjadjaran University, Bandung, Indonesia ${ }^{2}$ Department of Oral Biology, Faculty of Dentistry, Padjadjaran University, Bandung, Indonesia
*Correspondence to: Riani Setiadhi, Department of Oral Medicine, Faculty of Dentistry, Padjadjaran University, Bandung, Indonesia riani.setiadhi@unpad.ac.id

Received: 17 February 2017

Revised: 27 April 2017

Accepted: 21 June 2017

Available Online: 01 August 2017

\section{Introduction}

Pomegranate (punica granatum L.), one of the fruit plants often grows in the garden as ornamental tree and the fruit is edible as well. The pomegranate contains several major active components including flavonoids. ${ }^{1-5}$ The benefits of flavonoids are as antibacterial, antiviral, anti-insecticide and anti-inflammatory while the tannin substances as hemostatic, antibacterial, antioxidant and anti-inflammatory. ${ }^{6,7}$ The presence of flavonoids and tannins in pomegranate serving as antibacterial was suspected that it can fight against bacteria streptococcus sanguis (S. sanguis). ${ }^{8-11}$ The pomegranate fruit is often used as a traditional medicine, but it has not carried out an evaluation on the security level.

The primary aim of toxicological assessment of any herbal medicine is to identify adverse effects and to determine limits of exposure level at which such effects occur. Two important factors which are taken into consideration in evaluating the safety of any herbal drug are the nature and significance of the adverse effect and the exposure level where the effect is observed..$^{12,13}$

Toxicity tests can reveal some of the risks that may be associated with use of herbs and consist of two types: general toxicity and special toxicity. ${ }^{12,13}$ Acute toxicity is the degree of toxic effects of compound that occur in brief ( 24 hours) after a single dose administration. The acute toxicity test is one of the pre-test clinics, to measure the degree of the effect of toxic compounds occurring in short duration in a single dose in animals, the observations were conducted on the first 24 hours after treatment and was done only one time. ${ }^{14-16}$

The acute toxicity test of quantitative data can be obtained by two ways, i.e., the lethal dose $\left(\mathrm{LD}_{50}\right)$ and the toxic dose $\left(\mathrm{TD}_{50}\right)$. But the most frequently used method is the determination of the $\mathrm{LD}_{50}{ }^{12}$ A $L_{50}$ test is the early stage to know the safety materials to be used by humans in determining the magnitude of the dose that causes the death of $50 \%$ in test animals after a single dose administration. The $\mathrm{LD}_{50}$ of medicinal ingredient absolutely must be specified because this value is used in the assessment of the ratio of benefit and the power of the poison that is expressed as an index of drug therapy $\left(\mathrm{LD}_{50} / \mathrm{LE}_{50}\right) \cdot{ }^{17}$

An acute toxicity test (lethal dose) for pomegranate fruit has already been done, one of which is the pomegranate peel toxicity tests against the 
bacteria causing diarrhea. The results showed that the pomegranate were moderately toxic $(830.2 \mathrm{mg} /$ $\mathrm{kg}$ ) and the use of this material is still in the safe limit. ${ }^{18}$ The ethanol extract of pomegranate whole fruit and seeds and synthetic ellagic acid is practically non-toxic at single dose of oral administration in mice. No mortality was observed at the end of 24 hours period and the $\mathrm{LD}_{50}$ was thought to be greater than 2000 mg. ${ }^{19}$ Since there are limited information available on its toxicity, despite the widespread use of this medicinal plant, this study investigated acute toxicity of pomegranate seed extract to find its lethal dose values.

\section{Material and Methods}

This experimental research was carried out in The Laboratory of Chemistry Padjadjaran University and The Pharmacology and Laboratory Faculty of Medicine Padjadjaran University, Bandung. The pomegranate fruits were collected from the region of Cisarua Lembang, dried under the sun, mashed into powder and subjected to extraction with $70 \%$ ethanol. The powder was soaked in $70 \%$ ethanol for 24 hours, the macerate was screened and then evaporated with the rotary evaporator to obtain a stable extract of pomegranate seeds.

The minimum inhibitory concentration growth (MIC) and minimum bactericide concentration (MBC) of pomegranate seed extract against the bacteria S. sanguis ATCC 10556 were determined through several stages i.e. rejuvenating the bacteria, making the Mueller Hinton culture media $(\mathrm{MH})$, determining the Optical Density (OD), and by disc diffusion method test. The determination of MIC was carried out using microdilution method through 96-wells microplate. Every two rows of wells used Duplo data, such as media and samples in series 1 and 2 . The media and the solvent on series 3 and 4 . Media, sample and bacteria S. sanguis in series 5 and 6 . Lastly, was filled with media, solvents and the bacteri S. sanguis on series 7 and 8 . The dilution is carried out in stages starting from $8000 \mathrm{ppm}$ concentration. The ethanolic extract solution of Pomegranate seeds was made with the concentration of $0.2 \% / \mathrm{kg}$ BW equivalent to $40 \mathrm{mg} / \mathrm{kg}$ BW, $0.4 \% /$ $\mathrm{kg}$ BW equivalent to $80 \mathrm{mg} / \mathrm{kg}$ BW and $0.8 \% / \mathrm{kg}$ BW equivalent to $160 \mathrm{mg} / \mathrm{kg} \mathrm{BW}$.

An acute systemic toxicity test was performed for ethanolic extract of pomegranate seeds in 12 male and 12 female Swiss Webster mice weighing fasting but still were given drinking water and their behavior were observed. They were randomly divided into 4 groups of 3 males and 3 females each. Group A (control), were administered orally with aqua Dest, group B was administered $0.2 \%$ per kilogram, the group $C$ was administered $0.4 \%$ per kilogram and group $\mathrm{D}$ was administered $0.8 \%$ per kilogram. The test material were orally forcefully given using $1 \mathrm{ml}$ spuit appropriate with the weight of mouse and the effects were observed in 30, 60 and 120 minutes. The observed effects included: motoric activity, the Straub phenomenon, piloerection, ptosis, mydriasis, grooming, urination, defecation and salivation. Data of the dead mice were taken up to 24 hours after the extract were given, the surviving mice were observed for up to 7 days, then were anesthetized intra muscularly using $\mathrm{HCl}$ Ketamine $45 \mathrm{mg} / \mathrm{kg}$ body weight and the dead mice were cremated.

\section{Results}

The MIC of ethanolic extract of pomegranate seeds showed antibacterial properties against $\mathrm{S}$. sanguis

Table 1 shows ethanolic extract off pomegranate seeds have bacteriostatic activity against the bacteria S. sanguis ATCC 10556 with a minimum concentration of $2000 \mathrm{ppm}$ (at the 5th dilution), but not obvious as seen in figure 1 because the sample were colored and not clear thereby disrupting the analysis results and solvent (ethanol) inhibits the growth of bacteria to the 1st dilution. The $M B C$ value showed no bacterial growth in the media at the minimum concentration. The MBC of $1000 \mathrm{ppm}$ ethanolic extract of pomegranate seeds against $\mathrm{S}$. sanguis showed the presence of bacterial growth figure 2 but at the $2000 \mathrm{ppm}$ there were no bacterial growth, so the MBC value was $2000 \mathrm{ppm}$ figure 3.

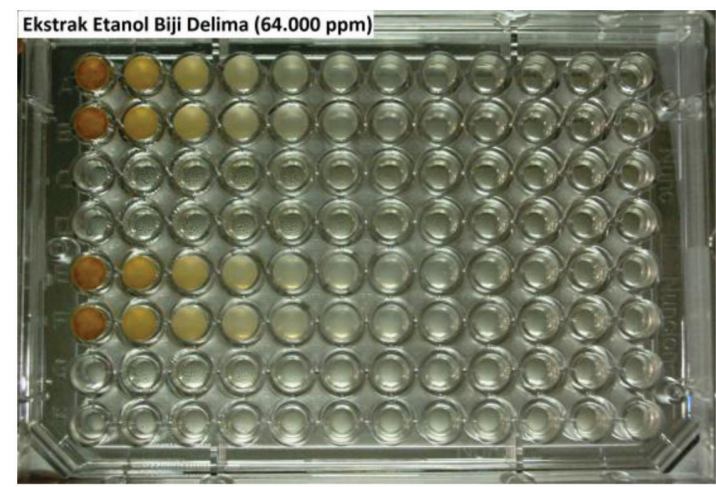

Figure 1 The MIC of ethanolic extract of pomegranate seeds against $\mathrm{S}$. sanguis 
Table 1 The results of MIC analysis of ethanolic extracts of pomegranate seeds against S. sanguis

\begin{tabular}{|c|c|c|c|c|c|c|c|c|c|c|c|c|}
\hline \multirow[b]{2}{*}{ Well } & \multicolumn{12}{|c|}{ Concentration } \\
\hline & 32000 & 16000 & 8000 & 4000 & 2000 & 1000 & 500 & 250 & 125 & 62.5 & 31.25 & 15.63 \\
\hline \multirow{2}{*}{ Media + Sample } & 1.242 & 1.009 & 0.768 & 0.496 & 0.303 & 0.204 & 0.144 & 0.105 & 0.079 & 0.066 & 0.057 & 0.051 \\
\hline & 1.251 & 1.059 & 0.774 & 0.494 & 0.31 & 0.208 & 0.147 & 0.106 & 0.078 & 0.064 & 0.057 & 0.054 \\
\hline \multirow{2}{*}{ Media + Solvent } & 0.075 & 0.049 & 0.049 & 0.047 & 0.048 & 0.049 & 0.047 & 0.049 & 0.051 & 0.05 & 0.049 & 0.049 \\
\hline & 0.064 & 0.049 & 0.048 & 0.047 & 0.046 & 0.046 & 0.047 & 0.046 & 0.047 & 0.048 & 0.049 & 0.048 \\
\hline \multirow{2}{*}{ Media + Sample + Bacteria } & 1.261 & 1.151 & 0.837 & 0.506 & 0.302 & 0.212 & 0.156 & 0.13 & 0.098 & 0.082 & 0.073 & 0.067 \\
\hline & 1.33 & 1.068 & 0.78 & 0.473 & 0.29 & 0.218 & 0.174 & 0.122 & 0.098 & 0.08 & 0.071 & 0.069 \\
\hline \multirow{2}{*}{ Media + Solvent + Bacteria } & 0.06 & 0.053 & 0.052 & 0.053 & 0.054 & 0.058 & 0.061 & 0.063 & 0.066 & 0.065 & 0.067 & 0.065 \\
\hline & 0.069 & 0.052 & 0.051 & 0.052 & 0.055 & 0.057 & 0.058 & 0.058 & 0.059 & 0.063 & 0.062 & 0.064 \\
\hline \multirow[t]{6}{*}{$\%$ Bacterial death } & 979.5 & -2156.8 & -1250 & 100.6 & 140.8 & -89 & -155 & -156 & -143 & -105 & -95.2 & -95.3 \\
\hline & 1.2465 & 1.034 & 0.771 & 0.495 & 0.307 & 0.206 & 0.146 & 0.106 & 0.079 & 0.065 & 0.057 & 0.053 \\
\hline & 0.0695 & 0.049 & 0.049 & 0.047 & 0.047 & 0.048 & 0.047 & 0.048 & 0.049 & 0.049 & 0.049 & 0.049 \\
\hline & 1.2955 & 1.1095 & 0.809 & 0.49 & 0.296 & 0.215 & 0.165 & 0.126 & 0.098 & 0.081 & 0.072 & 0.068 \\
\hline & 0.0645 & 0.0525 & 0.052 & 0.053 & 0.055 & 0.058 & 0.06 & 0.061 & 0.063 & 0.064 & 0.065 & 0.065 \\
\hline & 979.5 & -2156.8 & -1250 & 100.6 & 140.8 & -89 & -155 & -156 & -143 & -105 & -95.2 & -95.3 \\
\hline 64000 & 32000 & 16000 & 8000 & 4000 & 2000 & 1000 & 500 & 250 & 125 & 62.5 & 31.25 & 15.63 \\
\hline
\end{tabular}

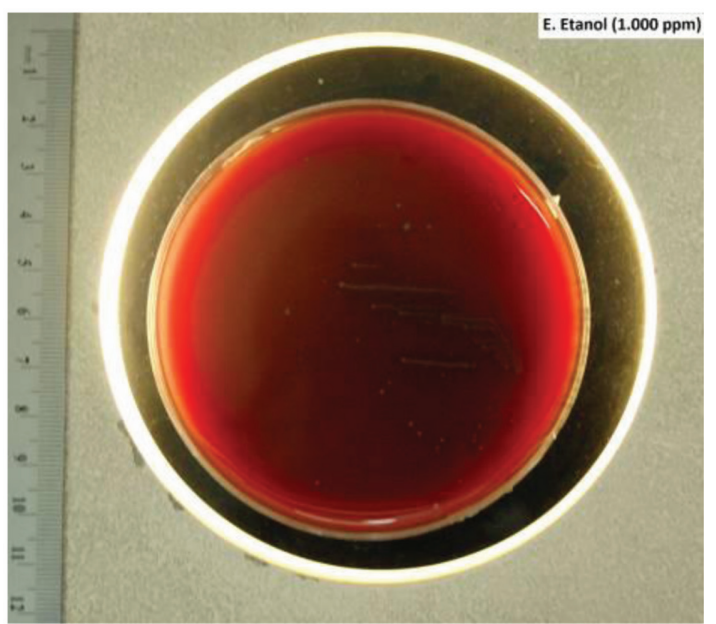

Figure 2 Shows MBC Of 1000 ppm ethanolic extract of pomegranate seeds against $\mathrm{S}$. sanguis

\section{Acute Toxicity of ethanolic extract of pomegranate seeds in Swiss Webster mice}

The Lethal Dose test $\left(\mathrm{LD}_{50}\right)$ of ethanolic extract of pomegranate seeds was given to Swiss Webster mice. Prior to test; all the mice in the control group and groups with various concentrations of ethanol have normal motor activities and did not experience the Straub phenomenon, piloerection, ptosis, mydriasis, grooming, urination, defecation or salivation and posttest.

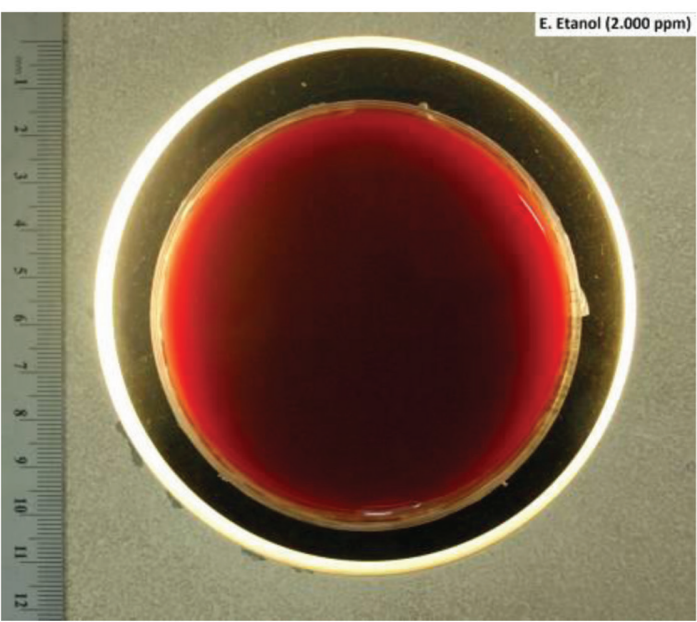

Figure 3 The MBC Of 2000 ppm ethanolic extract of pomegranate seeds against $\mathrm{S}$. sanguis

Table 2 describes the effects after 30, 60 and 90 minutes being given the test, all the mice in the control group showed normal motor activities. In the ethanolic extract group, all mice experienced decreased motor activity (the movement were reduced) at the beginning of the test, but after 60 minutes they were active again. All mice both in control and ethanolic extract group were not experiencing the Straub phenomenon, piloerection, ptosis, mydriasis, grooming, urination and defecation or salivation. 
Table 2 The observed effects after 30, 60 and 90 minutes

\begin{tabular}{|c|c|c|c|c|c|c|c|c|c|c|}
\hline & & $\begin{array}{l}\text { Motor } \\
\text { activity }\end{array}$ & $\begin{array}{c}\text { Straub } \\
\text { Phenomenon }\end{array}$ & Piloerection & Ptosis & Mydriasis & Grooming & Urination & Defection & Salivation \\
\hline \multirow{3}{*}{ Control } & $30^{\prime}$ & $\checkmark$ & - & - & - & - & - & - & - & - \\
\hline & $60^{\prime}$ & $\checkmark$ & - & - & - & - & - & - & - & - \\
\hline & $90^{\prime}$ & $\checkmark$ & - & - & - & - & - & - & - & - \\
\hline \multirow{3}{*}{$0.2 \%$ Ethanol } & $30^{\prime}$ & $\downarrow$ & - & - & - & - & - & - & - & - \\
\hline & $60^{\prime}$ & $\checkmark$ & - & - & - & - & - & - & - & - \\
\hline & $90^{\prime}$ & $\checkmark$ & - & - & - & - & - & - & - & - \\
\hline \multirow{3}{*}{$0.4 \%$ Ethanol } & $30^{\prime}$ & $\downarrow$ & - & - & - & - & - & - & - & - \\
\hline & $60^{\prime}$ & $\checkmark$ & - & - & - & - & - & - & - & - \\
\hline & $90^{\prime}$ & $\checkmark$ & - & - & - & - & - & - & - & - \\
\hline \multirow{3}{*}{$0.8 \%$ Ethanol } & $30^{\prime}$ & $\downarrow$ & - & - & - & - & - & - & - & - \\
\hline & $60^{\prime}$ & $\checkmark$ & - & - & - & - & - & - & - & - \\
\hline & $90^{\prime}$ & $\checkmark$ & - & - & - & - & - & - & - & - \\
\hline
\end{tabular}

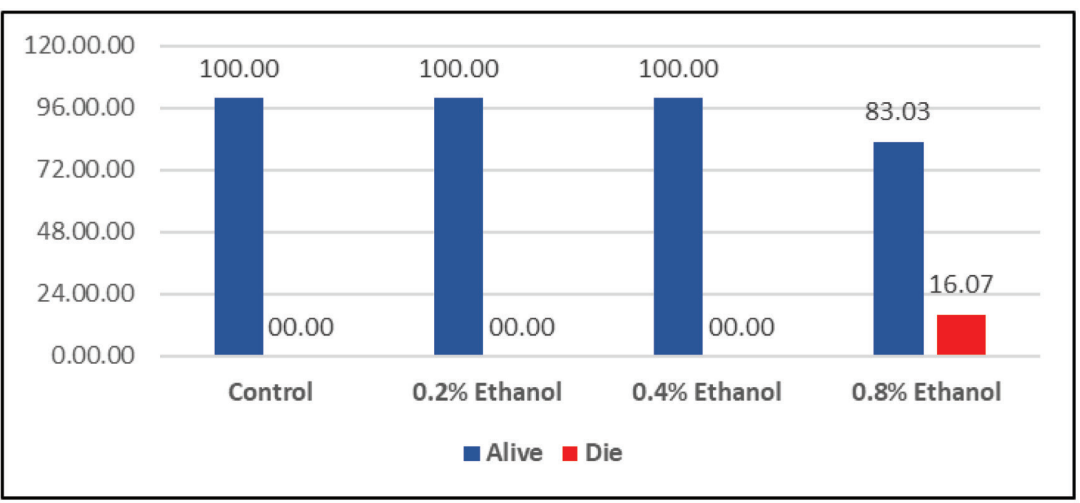

Figure 5 The results of observations in 7 days

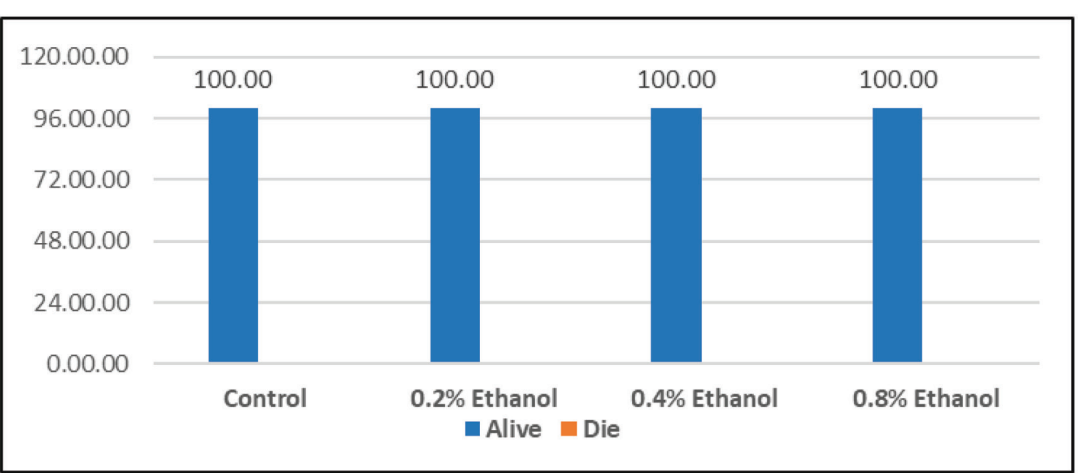

Figure 4 The results of observations in 24 hours

Table 3 and figure 4 showed the results of observation in 24 hours, all of the mice in each group's test were $100 \%$ alive and did not experience any disruptions.

Table 4 and figure 5 showed the results of observations during 7 days, all the mice in the control group, $0.2 \%$ and $0.4 \%$ ethanolic extract were still alive and did not experience any disruptions.
Table 3 Observations in $\mathbf{2 4}$ hours

\begin{tabular}{|c|c|c|c|c|c|c|}
\hline & \multicolumn{2}{|c|}{ Alive } & \multicolumn{2}{|c|}{ Die } & \multicolumn{2}{|c|}{ Total } \\
\hline & $\mathbf{n}$ & $\%$ & $\mathbf{n}$ & $\%$ & $\mathbf{n}$ & $\%$ \\
\hline Control & 6 & 100.0 & 0 & 0.0 & 6 & 100.0 \\
\hline $0.2 \%$ Ethanol & 6 & 100.0 & 0 & 0.0 & 6 & 100.0 \\
\hline 0.4\% Ethanol & 6 & 100.0 & 0 & 0.0 & 6 & 100.0 \\
\hline $0.8 \%$ Ethanol & 6 & 100.0 & 0 & 0.0 & 6 & 100.0 \\
\hline
\end{tabular}

Table 4 Observations in 7 days

\begin{tabular}{lccccccccc}
\hline & \multicolumn{2}{c}{ Alive } & & \multicolumn{2}{c}{ Die } & & \multicolumn{2}{c}{ Total } \\
\cline { 2 - 3 } & $\mathbf{n}$ & $\%$ & & $\mathbf{n}$ & $\%$ & & $\mathbf{n}$ & $\%$ \\
\hline Control & 6 & 100.0 & & 0 & 0.0 & & 6 & 100.0 \\
$0.2 \%$ Ethanol & 6 & 100.0 & & 0 & 0.0 & & 6 & 100.0 \\
$0.4 \%$ Ethanol & 6 & 100.0 & & 0 & 0.0 & & 6 & 100.0 \\
$0.8 \%$ Ethanol & 5 & 83.3 & & 1 & 16.7 & & 6 & 100.0 \\
\hline
\end{tabular}

While at the $0.8 \%$ ethanolic extract, 5 mice $83.3 \%$ were still alive and 1 mice $16.7 \%$ died.

\section{Discussion}

The MIC of pomegranate seeds' ethanolic extract is $2000 \mathrm{ppm}$ and the $\mathrm{MBC}$ is $2000 \mathrm{ppm}$, which means ethanolic extract have bacteriostatic and bactericidal activity against the bacteria S. sanguis ATCC 10556 with a minimum concentration of $2000 \mathrm{ppm}$. The MBC value of pomegranate seeds' ethanolic extract is $2000 \mathrm{ppm}$, which is equivalent to $0.2 \%$ is the reason why the concentration of extracts will be used in this study at a minimum of $0.2 \%$.

The result of $\mathrm{LD}_{50}$ toxicity test of pomegranate seeds' ethanolic extract showed that there was one 
mouse dead after the 7 th day of test, at the $0.8 \%$ concentration equivalent to $160 \mathrm{mg} / \mathrm{kg}$ body weight which was given systemically. When the dose is converted in to an adult human body weight calculations, e.g. $60 \mathrm{~kg}$, the limited toxic dose is $9600 \mathrm{mg}$. This result indicated that death occurs at a very high systemic dose and it is a safe material especially if used topically. This is in accordance with Sundari $\mathrm{D}$ et al. ${ }^{18}$ they stated that the pomegranate were moderately toxic $(830.2 \mathrm{mg} / \mathrm{kg})$ and the use of this material is still in the safe limit. ${ }^{18}$ Bhandary et al. ${ }^{19}$ also stated that the ethanol extract of the entire pomegranate fruit and it seeds and synthetic ellagic acid is practically non-toxic at single dose oral administration in mice. No mortality was observed at the end of 24 hours period and the $\mathrm{LD}_{50}$ was thought to be greater than $2000 \mathrm{mg} .{ }^{19}$

The MBC concentration is $2000 \mathrm{ppm}$ or equivalent to $2000 \mathrm{mg} / \mathrm{kg}$ and also $2000 \mathrm{mg} / \mathrm{l}$. If the extract is used as a mouth rinse (topical) and available in bottles of $60 \mathrm{ml}$, then the required weight extract is $120 \mathrm{mg}$ to achieve a concentration of $2000 \mathrm{ppm}$. Based on these calculations, the bactericide effect arises in $120 \mathrm{mg}$ in $60 \mathrm{ml}$ mouthwash for topical use, which is afar from the toxic dose at $9600 \mathrm{mg}$.

\section{Conclusion}

Pomegranate seeds' ethanolic extract has antibacterial effect and has passed the toxicity test, and also proven by the concentration of toxic dose which is greater than $160 \mathrm{mg} / \mathrm{kg}$ of body weight with effective minimum dose at $120 \mathrm{mg} / 60 \mathrm{ml}$.

\section{Acknowledgement}

The authors would like to thank the Lord Almighty for given us the opportunity to complete this research and to the Dean of Faculty of Dentistry, University of Padjadjaran, who facilitated us with funding for this research, and to all staffs, laboratory workers at the chemical laboratory of the Faculty of Mathematics and Natural Sciences and also the Animal Laboratory Pharmacology and Therapy Department of Medical Faculty of University of Padjadjaran, for helping us in conducting this research.

\section{Conflict of Interest}

The authors report no conflict of interest.

\section{References}

1. Jurenka J. Therapeutic applications of pomegranate (punica granatum L.): a review. Alt Med Review 2008;13: 128-131, 137-138, 141.

2. Marhari OY, Dewi KK. Khasiat ajaib delima. 1st ed. Jakarta: Padi; 2014. p. 1-5, 23-24, 63.

3. Suranto A. Terbukti pome tumpas penyakit. 1st ed. Jakarta: Pustaka Bunda; 2011. p. 1-15, 31-33.

4. Arun N, Singh DP. Punica granatum: a review on pharmacological and therapeutic properties. Int J Pharma Sci \& Res 2012;3: 1240-1245.

5. Yasoubi P. Total phenolic contents and antioxidant activity of pomegranate (punica granatum L.) peel extracts. J Agriculture Sci Technol 2007;9: 35-42.

6. Prashanth D, Asha MK, Amit A. Antibacterial activity of punica granatum. fitoterapia 2001;72: 171-173.

7. Abdollahzadeh Sh. Antibacterial and antifungal activities of punica granatum peel extracts against oral pathogens. Journal of Dentistry. Tehran University of Med Sci 2011;8.

8. Kumar A, Vijayalakhsmi K. In vitro antimicrobial activity and phytochemical analysis of selected fruit wastes. Int J Current Microbiology and Applied Sci 2013;2: 196-204.

9. Nuamsetti T, Dechayuenyong $P$, Tantipaibulvut S. Antibacterial activity of pomegranate fruit peels and arils. Sci Asia 2012;38: 319-322.

10. Naziri Z, Rajaian H, Firouzi R. Antibacterial effects of Iranian native sour and sweet pomegranate (punica granatum) peel extracts against pathogenic bacteria. Iranian J Veterinary Res 2012;13.

11. Vasconcelos LCS. Minimum inhibitory concentration of adherence of punica granatum linn (pomegranate) gel against S. mutans, S. mitis and C. albicans. Braz Dent J 2006; 17: 223-227.

12. Obidike I, Salawu O. Screening of herbal medicines for potential toxicities, new insights into toxicity and drug testing.

13. Amiria FD. Uji Toksisitas Akut Obat Herbal. FMIPA Universitas Indonesia. 2008. p. 5-8.

14. Sulastry F, Surastri B. Uji toksisitas akut yang diukur dengan penentuan LD 50. Universitas Diponegoro 2009. p. $10-13$.

15. Gad SC. Acute toxicity testing in drug safety evaluation.

16. Kumar P. Acute and sub-acute ( 28 day) oral toxicity studies of ethanolic extract of celtis timorensis leaves in rodent. Global J Med Res 2014;14.

17. Soemardji AA, Kumolosasi E, Aisyah C. Toksisitas akut dan penentuan dl50 oral ekstrak air daun gandarusa (justicia gendarussa burm F.) pada mencit swiss webster. Jurnal Matematika dan Sains 2002;7: 57-62.

18. Sundari D, Nuratmi B, Soekarso T. Efek antibakteri ekstrak kulit buah delima (punica granatum 1) terhadap bakteri penyebab diare secara in vitro dan uji toksisitas akut. Litbangkes 1998;3: 38-41.

19. Bhandary BSK. Acute and subacute toxicity study of the ethanol extracts of punica granatum (linn) whole fruit and seeds and synthetic ellagic acid in Swiss albino mice. Asian J Pharmaceutical \& Clinical Res 2013;6: 192-198.

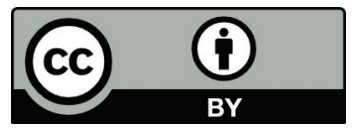

This work is licensed under a Creative Commons Attribution 